\title{
External Fixation of Femoral Shaft Fractures in Spinal Cord Injury Patients
}

\author{
Robert A. Baird, M.D., ${ }^{1,2}$ Arthur Kreitenberg, M.D. ${ }^{1}$ and Ibrahim \\ Eltorai, M.D. ${ }^{3}$ \\ ${ }^{1}$ Division of Orthopaedic Surgery of the University of California at Irvine, \\ ${ }^{2} S T$ AMP Program and the ${ }^{3}$ Spinal Cord Injury Service of the Long Beach Veterans \\ Administration Medical Center, Long Beach, California, U.S.A.
}

\section{Summary}

External fixation was used to treat femoral shaft fractures in nine spinal cord injury (SCI) patients. One patient died of unrelated causes during fracture treatment. Of the remaining eight patients, seven healed their fractures. Two complications, one superficial pin-track drainage and one fracture comminution, occurred in the nine patients. Neither complication adversely affected the patient's final result.

In patients with acute spinal cord injury, external fixation should be considered for the treatment of closed femoral shaft fractures with marked comminution, and for open femoral shaft fractures with significant contamination or soft tissue loss. In the chronic SCI patient, external fixation of a femoral shaft fracture may increase the patient's level of independence and mobility during fracture healing, and may permit a more rapid return to the patient's pre-fracture functional level.

Key words: Femoral shaft fractures; Spinal cord injury; Paraplegia; Quadriplegia.

\section{Introduction}

Fractures of the femur are common injuries in spinal cord injury patients. In a patient with an acute spinal cord injury (SCI), the femoral fracture often occurs as one facet of a multi-system injury. In a patient with a chronic spinal cord injury, the femoral shaft fracture usually occurs as an isolated injury from minor trauma to a pathologically weakened bone. Because the patient with an acute spinal cord injury presents with femora of normal mineral content, the need for rapid mobilization to permit rehabilitation, and the lack of physiologic problems associated with chronic spinal cord injuries such as negative nitrogen balance and recurrent bacteraemias, intramedullary rodding or open reduction with internal fixation are the treatment modalities most commonly preferred for femoral fractures in patients with acute spinal cord injuries. Conversely, because of the physiological changes which occur with chronic spinal cord injury including negative nitrogen balance, recurrent bacteraemias, the presence of marked osteoporosis, and other metabolic changes, external splintage using padded splints is the most commonly accepted method of treatment for femoral shaft fractures in the chronic spinal cord injury patient. 
There are times, however, when alternative methods of treatment need to be explored. In a patient with an acute spinal cord injury, intramedullary rodding or open reduction with internal fixation may be technically difficult in fractures with marked comminution, and may be inadvisable in the treatment of open fractures with significant contamination or soft tissue loss. In the chronic spinal cord injury patient, external splintage with a long-leg or hip spica splint may diminish the patient's mobility, reduce his level of independence, and may require hospitalization for adequate supportive care.

We have used external fixation as an alternative method of treatment for femoral shaft fractures in patients with both acute and chronic spinal cord injuries. This paper reports the indications, technique, and results of external fixation of femoral shaft fractures in our spinal cord injury patient population.

\section{Materials and Methods}

Spinal cord injury patients with a femoral fracture between a point $2.5 \mathrm{~cm}$. distal to the lesser trochanter and a point $6.0 \mathrm{~cm}$. proximal to the tibiofemoral joint line were considered candidates for external fixation if they met the following criteria:Acute spinal cord injury patients with:

1. An open femoral fracture with significant contamination or soft tissue loss.

2. Significant fracture comminution making intramedullary rodding or internal fixation either technically difficult or contra-indicated.

3. Concurrent infection, or other physiological problem, contra-indicating the use of internal fixation devices.

Chronic spinal cord injury patients with:

1. A femoral fracture the splinting of which would significantly diminish either the patient's functional abilities including the ability to use a wheelchair, drive a motor vehicle, and return to work, or the patient's level of independence and ability for self-care.

Patients who met these criteria were advised concerning alternative methods of treatment. Patients with active urinary tract infections were treated with oral antibiotics and surgery was delayed until suppression was achieved. Application of the external fixation device was done under general anaesthesia in patients with incomplete spinal cord lesions and the presence of sensation in the lower extremities. The procedures were performed without anaesthesia for patients with complete spinal cord injuries and insensitive lower extremities. Sedation with intravenous diazepam was used as necessary. External fixation devices used in this series included Ace-Fisher external fixators, Ortho-Fix fixators, and Wagner leg-lengthening devices. The Ace-Fisher external fixators were placed using a triangular configuration with two pair of half-pins placed into the anterior and lateral cortices of the proximal femur in the sagittal and frontal planes respectively. Distal fixation was achieved using a set of three full-pins placed in the frontal plane of the distal femoral shaft. Because of difficulties encountered with the distal full pins during treatment of the first two patients with Ace-Fisher frames, the remaining six patients were treated with either Ortho-Fix fixators or Wagner leg-lengthening devices, both unilateral fixators using half-pins. The fixation pins were inserted into the femur using standard techniques after closed reduction of the femoral fracture. (Baird, 1984) The fixators were attached to the 
pins two $\mathrm{cm}$ from the skin surface with the thigh resting on the operating room table permitting placement of sterile dressings around the pins where they entered the skin. The pins were cut just lateral to the pin clamps to reduce lateral extension of the pins, and the ends of the pins were covered with rubber tubing to prevent injury to the patient, mattresses, and cushions from the sharp cut ends.

Postoperatively, paraplegic patients, their family, or their home aides were taught to change the pin-site dressings. Patients were discharged from the hospital when adequate ability to care for the pin-sites was achieved, or when other medical and social problems requiring hospitalization were resolved. Following fracture union, the fixator and pins were removed on an outpatient basis without anaesthesia. Gauze wicks were placed in the pin-site wounds and patients were advised to remove the wicks after forty-eight hours. Patients were given oral dicloxicillin or cephalexin for forty-eight to seventy-two hours after removal of the fixation pins.

\section{Results}

Between 1981 and 1984 we treated nine femoral fractures in nine spinal cord injury patients using external fixation devices (Table 1). All of the patients were male. Patient ages ranged from twenty-one to seventy-one years with a mean age of forty-seven years. Four of the patients were quadriplegic, and five were paraplegic. Eight patients had complete spinal cord lesions. One patient had an incomplete spinal cord injury. Two patients sustained their femoral fractures concurrent with the acute spinal cord injury. In the seven patients with chronic spinal cord injuries the femoral fracture was their sole injury at the time of treatment. In this latter group, the femoral fractures were classified as pathological according to the classification of McMaster and Stauffer, having been caused by minor trauma to a femur weakened by osteoporosis. (McMaster, 1975).

Eight of the nine femoral fractures were closed injuries. The one open fracture in this series was associated with a contralateral closed femoral shaft fracture. Both fractures were sustained at the time of the acute spinal cord injury. This patient's (Case 7) contralateral fracture was treated with closed intramedullary rodding. One of the fractures in this series was located in the proximal third of the femur, three in the middle third, and five in the distal third.

The interval between the acute femoral fracture and the application of the external fixation device ranged between one and six weeks, with a mean interval of two and one-half weeks. The delay between fracture and device application was attributable to several factors including delay in diagnosis (in chronic SCI patients), delay in transfer to our institution, or delay in surgery scheduling. External fixators used included two Ace-Fisher frames, one Ortho-Fix device, and five Wagner leg-lengthening devices.

The external fixation devices were in place for periods ranging from one and one-half to seventeen weeks with a mean treatment period of nine weeks. One of the nine patients did not complete treatment. This patient (Case 4), a fifty-nine year old man with a complete C-5 spinal cord injury, sustained a closed fracture of the middle third of the femur which was treated with a Wagner leg-lengthening device. Four weeks after application of the device the patient died of complications of chronic renal failure and inappropriate anti-diuretic hormone syndrome. The 
Table I Clinical Data

\begin{tabular}{|c|c|c|c|c|c|c|c|c|c|}
\hline Case & $\begin{array}{c}\text { Age } \\
\text { (years) }\end{array}$ & $\begin{array}{c}\text { Level and } \\
\text { completeness of } \\
\text { neurologic lesion }\end{array}$ & $\begin{array}{l}\text { Type and } \\
\text { location } \\
\text { of Femur } \\
\text { Fracture }\end{array}$ & $\begin{array}{l}\text { Acute Versus } \\
\text { Chronic S.C.I. }\end{array}$ & $\begin{array}{l}\text { Time from } \\
\text { Fracture } \\
\text { to Device } \\
\text { Application } \\
\text { (Weeks) }\end{array}$ & $\begin{array}{c}\text { Type of } \\
\text { Device Used }\end{array}$ & $\begin{array}{l}\text { Time Device } \\
\text { in Place } \\
\text { (Weeks) }\end{array}$ & Outcome & Comments \\
\hline 1 & $\overline{2} 1$ & $\begin{array}{c}\text { C-6 } \\
\text { Incomplete }\end{array}$ & $\begin{array}{l}\text { Closed } \\
\text { Distal third }\end{array}$ & Acute & 5 & Ace-Fisher & 11 & $\begin{array}{l}\text { Fracture } \\
\text { Healed }\end{array}$ & $\begin{array}{l}\text { Femur refractured after device } \\
\text { removal; subsequently healed in } \\
\text { padded splint. }\end{array}$ \\
\hline 2 & 52 & $\begin{array}{c}\mathrm{T}-12 \\
\text { Complete }\end{array}$ & $\begin{array}{c}\text { Closed } \\
\text { Middle third }\end{array}$ & Chronic & 1 & Ace-Fisher & 9 & $\begin{array}{l}\text { Fracture } \\
\text { Healed }\end{array}$ & \\
\hline 3 & 55 & $\begin{array}{c}\mathrm{T}-5 \\
\text { Complete }\end{array}$ & $\begin{array}{l}\text { Closed } \\
\text { Distal third }\end{array}$ & Chronic & 1 & Ortho-Fix & 1.5 & $\begin{array}{l}\text { Fracture } \\
\text { Healed }\end{array}$ & $\begin{array}{l}\text { Comminution of distal fragment } \\
\text { by tapered pins; subsequently } \\
\text { healed in padded splint. }\end{array}$ \\
\hline 4 & 59 & $\begin{array}{c}\text { C-5 } \\
\text { Complete }\end{array}$ & $\begin{array}{c}\text { Closed } \\
\text { Middle third }\end{array}$ & Chronic & 6 & Wagner & 4 & Deceased & $\begin{array}{l}\text { Patient died of complications of } \\
\text { renal failure and inappropriate } \\
\text { antidiuretic hormone syndrome } \\
\text { after four weeks of treatment. }\end{array}$ \\
\hline 5 & 71 & $\begin{array}{c}\mathrm{T}-10 \\
\text { Complete }\end{array}$ & $\begin{array}{c}\text { Closed } \\
\text { Distal third }\end{array}$ & Chronic & 5 & Wagner & 17 & Non-Union & $\begin{array}{l}\text { Patient developed superficial pin- } \\
\text { tract drainage; patient has had } \\
\text { non-union of previous fracture of } \\
\text { contralateral femur. }\end{array}$ \\
\hline 6 & 55 & $\begin{array}{c}\text { C-7 } \\
\text { Complete }\end{array}$ & $\begin{array}{c}\text { Closed } \\
\text { Distal third }\end{array}$ & Chronic & 5 & Wagner & 14 & $\begin{array}{l}\text { Fracture } \\
\text { Healed }\end{array}$ & \\
\hline 7 & 30 & $\begin{array}{c}\text { C-6 } \\
\text { Complete }\end{array}$ & $\begin{array}{c}\text { Open } \\
\text { Middle third }\end{array}$ & Acurte & 2 & Wagner & 7 & $\begin{array}{l}\text { Fracture } \\
\text { Healed }\end{array}$ & \\
\hline 8 & 50 & $\begin{array}{c}\mathrm{T}-11 \\
\text { Complete }\end{array}$ & $\begin{array}{c}\text { Closed } \\
\text { Distal third }\end{array}$ & Chronic & 2 & Wagner & 10 & $\begin{array}{l}\text { Fracture } \\
\text { Healed }\end{array}$ & \\
\hline 9 & 36 & $\begin{array}{c}\mathrm{T}-3 \\
\text { Complete }\end{array}$ & $\begin{array}{l}\text { Closed } \\
\text { Proximal } \\
\text { third }\end{array}$ & Chronic & 2 & Wagner & 7 & $\begin{array}{l}\text { Fracture } \\
\text { Healed }\end{array}$ & \\
\hline
\end{tabular}


fracture healed in seven of the eight patients who completed treatment. The patient who developed non-union was a seventy-one year old man with a complete $\mathrm{T}-10$ spinal cord injury who sustained a right closed distal femur fracture. His past medical history included the presence of a long standing non-union of a similar fracture of the left femur. The right femoral fracture was treated with a Wagner leg-lengthening device for seventeen weeks. At the end of this period of time it was apparent that there was no progression toward healing and the device was removed. An open reduction and internal fixation using a compression plate, iliac crest bone graft, and polymethylmethacrylate supplementation was subsequently performed with eventual fracture healing.

Two complications occurred in the nine patients in this series. One patient (Case 5) developed a superficial pin-track drainage which responded to treatment with oral antibiotics. One patient (Case 3) sustained communition of the distal femoral fracture fragment when the distal pins were inserted. This patient was treated with an Ortho-Fix device using pins with tapered points. These taperpointed pins are designed to be self-tightening when screwed into normal cortical bone. In the spinal cord injury patient with significant osteoporosis, the cortical bone may not be able to withstand the stress created by the increasing diameter of the pin as it is screwed into the femoral shaft, and comminution of the femoral fragment rather than tightening of the pin may occur. We have subsequently discontinued use of this device because of the tapered configuration of the pins. Of the two complications, only one (Case 3 ) required early removal of the fixator. Neither complication adversely influenced the result of treatment.

One patient (Case 1) sustained a refracture shortly after removal of the fixation device. This patient, a twenty-one year old male with an acute incomplete C-6 spinal cord injury sustained a fracture of the distal femoral shaft concurrent with his spinal injury. The patient suffered from severe spasticity in the lower extremities which was unresponsive to medical management. The patient's femur fracture was initially treated in skeletal traction. After five weeks of treatment, however, the patient continued to have significant mobility and pain at the fracture site with marked angular deformity occurring during the patient's severe muscle spasms. An Ace-Fisher external fixator was placed upon the patient. After eleven weeks of treatment it was felt that the fracture was adequately healed and the fixator was removed. Shortly after removal of the fixator the patient refractured through the original fracture site during a muscle spasm. He was treated in a long-leg padded splint and the femoral fracture subsequently healed. We believe that an error in judgement was made in this patient's case regarding the adequacy of bone healing at the time removal of the fixation device was considered, and that premature removal of the device predisposed to refracture.

Four of the seven patients who completed treatment with the external fixation devices were able to return home and be treated as an outpatient for some period of time prior to removal of their external fixation device. Of the remaining three patients, one patient expired and two patients required continued hospitalization for their rehabilitation program. Seven patients were able to resume using their wheelchair during treatment of their fracture. The two exceptions were a patient who was bedridden because of medical problems and the patient whose external fixator was removed because of fracture comminution and loss of pin fixation. 


\section{Discussion}

Femoral fractures are the most common long-bone fractures in both acute and chronic SCI patients. (Comarr, 1962; Ragnarsson, 1981) In both groups of patients, the main goal of treatment is the preservation of as much function as possible within the limitations created by the spinal cord injury. (Freehafer, 1981; McMaster, 1975) During treatment, mobility should be maintained in an effort to decrease the negative physiological effects of immobilization. (Eichenholtz, 1963) For SCI patients who are expected to resume ambulation after fracture healing, normal femoral length, alignment, and rotation should all be maintained to optimize ambulatory potential. For those patients who are not expected to resume ambulation, normal femoral length and angular alignment need not be maintained as moderate femoral shortening and angular deformity rarely cause functional problems in non-ambulators. (Azaria, 1983) Normal femoral rotational alignment should be maintained, however, as femoral rotation determines the angular alignment of the tibial shaft when the patient sits with the knee flexed.

Intramedullary rodding and open reduction with internal fixation are the most widely accepted methods of treatment for femoral shaft fractures in acute SCI patients. (McMaster, 1975; Nottage, 1981) Although non-operative treatment of femoral shaft fractures may be used in these patients, it is associated with a $50^{\circ}{ }_{0}$ non-union rate, and delayed rodding may become necessary. (Nottage, 1981)

In the patient with a chronic spinal cord injury, the most widely accepted method of treatment is external splintage using padded or pillow splints. (Azaria, 1983; Comarr, 1962; Eichenholtz, 1963; El Ghatit, 1981; Freehafter, 1981) Other treatment methods commonly employed in non-SCI patients present various disadvantages in the SCI patient population. The use of circumferential plaster casts or skin traction is undesirable because of the SCI patient's anaesthetic skin. (Eichenhltz, 1963; McMaster, 1975) Although skeletal traction may be indicated in certain cases, (Freehafer 1965) skeletal traction may predispose the SCI patient to decubitus ulcer formation and other complications of immobilization. (Eichenholtz, 1963) Internal fixation of femoral shaft and distal femoral fractures is associated with a high complication rate in chronic SCI patients secondary to their negative nitrogen balance, recurrent bacteraemias, urinary tract infections, osteoporosis, and skin vascular changes. (Azaria, 1983; Comarr, 1962; Eichenholtz, 1963; Freehafer, 1965; Freehafer, 1981; Ragnarsson, 1981) As anatomical position and alignment is not critical for either healing or function in this patient population, closed treatment using padded or pillow splints has proved to be an adequate method of treatment. Appropriately splinted, the majority of these fractures heal without difficulty, often with exuberant callus formation. Non-unions do occur, however. (Comarr, 1962; Freehafer, 1965; Michaelis, 1964) Although one series reported a $26^{\circ}{ }_{0}$ femoral non-union rate, (McMaster 1975) a more representative non-union rate for this patient population is less than $10 \%$. (Michaelis, 1964)

Although intramedullary rodding and open reduction with internal fixation for the acute SCI patient, and external splintage with padded or pillow splints for the chronic SCI patient yield acceptable results, there are times when external fixation may be indicated. In the acute SCI patient, external fixation should be considered in the presence of significant fracture comminution, the presence of an open fracture of the femur with significant contamination of soft tissue loss, or in the 
presence of concurrent infection or other physiologic problem contra-indicating the use of an internal fixation device. In chronic SCI patients, external splintage of a femoral shaft fracture may significantly diminish the patient's functional abilities including his ability to use a wheelchair, drive a motor vehicle, or return to work. The patient's level of independence and his ability to perform self-care may be diminished, and hospitalization may be required. In such instances, external fixation may permit the patient to resume use of his wheelchair, drive a motor vehicle, and return to work at a desk or other work space too confined for the use of a wheelchair leg extender and pillow splint. Recently, Levine and others (Levine, 1984) reported significant complications with the use of external fixators in two spinal cord injury patients. They stated that the external fixation devices interfered with patient positioning and joint motion, predisposed to trophic ulcers, and may have delayed rather than promoted fracture union. Their two patients were treated with bulky external fixation frames using full-pin fixation. We believe that many of the complications they experienced may be avoided by the use of a non-bulky unilateral fixation device such as the Wagner leg-lengthening device, the use of half-pin fixation, aggressive patient mobilization including passive hip and knee range of motion exercises, and early resumption of wheelchair activities.

Our experience with the use of external fixation in nine SCI patients has been favourable. Although two of our patients sustained complications, neither complication adversely affected the end result of the treatment. Additionally, one of these two complications was felt to have been due to the use of tapered fixation pins which we have discontinued using. Because intramedullary rodding or open reduction with internal fixation, and external splintage, have been proven to be acceptable methods of treatment for femoral shaft fractures in the acute and chronic SCI patient respectively, the use of external fixation for the treatment of such fractures should not be considered as a primary method of treatment until further experience with this technique has been collected. However, our experience has led us to believe that external fixation is an alternative method of treatment with acceptable complication rates and results in the spinal cord injury patient who may benefit from its potential advantages.

\section{Résumé}

On a mené une étude rétrospective de 106 souffrants tétraplégiques admis consécutivement au Centre Médical de la Vallée de Santa Clara (SCVMC) entre août 1981 et septembre 1983. L'âge moyen de ceux-ci était de 28 ans; et $20\left(19^{\circ}{ }_{0}\right)$ en étaient femelles. La plupart en ont reçu leur blessure de la moelle épinière dans un accident d'automobile $\left(65^{\circ}{ }_{0}\right)$ ou dans un accident de plongée $\left(19^{\circ}{ }_{0}\right)$. Quarante-neuf pour cent $(52 / 106)$ de ces souffrants avaient une intervention chirurgique aiguë et $63^{\circ}{ }_{0}(33 / 52)$ de ces souffrants-ci avaient subi celle-ci avant l'admission au SCVMC. La plupart $(35 / 52)$ en avaient une fusion postérieure seulement. Douze souffrrants avaient une fusion antérieure (dont 11 à d'autres hôpitaux) et quatre une laminectomie seulement (dont trois exécutées à d'autres hôpitaux).

La durée du séjour de réhabilitation était de 133 jours pour ceux qui ont subi une intervention chirurgique, et de 119 jours pour les cas non-chirurgiques; différence statistiquement non significative. Quand on combinait les jours d'hospitalisation médicale/chirurgique et de réhabilitation, ceux qui avaient subi une intervention chirurgique avaient un séjour significativement plus long (197 jours contre 153), mais seulement quand cette intervention a été effectuée ailleurs qu'au SCVMC. Des complications se sont produites chez $50 / 106\left(47^{\circ}{ }_{0}\right)$ des souffrants: $50^{\circ}{ }_{0}$ qui avaient subi une intervention chirurgique et $44^{\circ}{ }^{\circ}$ qu'on traitait conservativement. La complication la plus commune était respiratoire $\left(43^{\circ}{ }_{0}\right)$, dont $20^{\circ}{ }_{0}$ qui souffraient de la pneumonie. Les complications n'étaient pas plus marquées chez ces souffrants qui ont subi une fusion postérieure que chez ceux qui 
n'ont subi aucune intervention chirurgique vertébrale. Cependant, les autres types d'intervention chirurgique comportaient un plus grand risque de complications de l'ordre de $20^{\circ}$ o approximativement. Les fusions antérieures et les laminectomies, exécutées presque totalement à d'autres institutions (15/17), avaient un taux de complications plus élevé.

\section{Zusammenfassung}

Man hat ein rückblickendes Studium von 106 im Medizinischen Zentrum des Santa Clara-Tals (SCVMC) zwischen August 1981 und September 1983 aufeinanderfolgend aufgenommenen tetraplegischen Patienten. Das Durchschnittsalter war 28 Jahre; und $20\left(19^{\circ}{ }_{0}\right)$ waren weiblich. Die meisten haben ihre Rückenmarkverletzung in einem Autounfall $\left(65^{\circ}{ }_{0}\right)$ oder in einem Tauchenunfall $\left(19^{\circ}{ }_{0}\right)$ gelitten. Neunundvierzig prozent $(52 / 106)$ von diesen Patienten hatten akuten chirurgischen Eingriff, und $63^{\circ}{ }_{o}(33 / 52)$ von diesen Patienten hatten ihn schon vor der Aufnahme im SCVMC. Die meisten (35/52) hatten nur hintere Wirbelvereinigung. Zwölf Patienten hatten eine vordere Wirbelvereinigung (11 in anderen Krankenhäusern) und vier eine Laminektomie allein (wovon drei in anderen Krankenhäusern ausgeführt).

Die Dauer der wiederherstellungsmässigen Unterbringung im Krankenhaus betrug 133 Tage für die chirurgisch behandelten Patienten, und 119 Tage für die nichtchirurgischen Fälle, ein statistisch unbedeutender Unterschied. Wenn man die für akute medizinische/chirurgische Behandlung und für Wiederherstellung notwendigen Tage kombinierte, hatten die chirurgisch behandelten Patienten eine bedeutend längere Unterbringung im Krankenhaus (197 Tage gegen 153), aber nur wenn der chirurgische Eingriff wo anders als im SCVMC ausgeführt worden ist. Komplikationen sind bei 50/106 $\left(47^{\circ}{ }_{\circ}\right)$ der Patienten vorgekommen: $50^{\circ}{ }_{0}$, die chirurgisch und $44^{\circ}{ }_{0}$, die konservativ behandelt wurden. Die gewöhnlichste Komplikation betraf die Atmung $\left(43^{\circ}{ }_{0}\right)$, einschliesslich $20^{\circ}{ }_{o}$, die Pneumonie hatten. Komplikationen waren keineswegs grösser bei den Patienten, die hintere Wirbelvereinigung erlitten haben, als bei den ohne Rückengratchirurgie behandelten. Doch, trugen andere Arten Chirurgie ein ungefähr $20^{\circ}$ • grösseres Risiko von Komplikationen. Vordere Wirbelvereinigungen und Laminektomien, fast alle in anderen Institutionen ausgeführt (15/17), hatten ein höheres Komplikationsverhältnis.

\section{References}

Azaria M, ANner A, OHry A Long bone fractures in the spinal cord injured patient. Orthopaedic Review. 12:69-75

BAIRD R, KREITENBERG A 1984 Treatment of femoral shaft fractures in the spinal cord injury patient using the Wagner leg lengthening device. Paraplegia 22:366-372

COMARR A, Hutchison R, Bors E 1962 Extremity fractures of patients with spinal cord injuries. American Journal of Surgery 103:732-739

EichenHoltZ S 1963 Management of long-bone fractures in paraplegic patients. Journal of Bone and Joint Surgery 45A:299-310

El Ghatit A, Lamid S, Flatley T 1981 Case Report: Posterior splint for leg fractures in spinal cord injured patients. American Journal of Physical Medicine 60:239-242

Freehafer A, HAzel C, Becker C 1981 Lower extremity fractures in patients with spinal cord injury. Paraplegia 19:367-372

FREEHAFER A, MAST W 1965 Lower extremity fractures in patients with spinal-cord injury. Journal of Bone and Joint Surgery 47A:683-694

LeVine A, KREBS M, SANTOS-Mendoza N 1984 External fixation in quadriplegia. Clinical

Orthopaedics 184:169-172

MCMASTER W, STAUFFER ES 1975 The management of long bone fracture in the spinal cord injured patient. Clinical Orthopaedics 112:44-52

MiCHAELIS LS 1964 Orthopaedic surgery of the limbs in paraplegia. Springer-Verlag, Berlin, p 26

NotTAGE W 1981 A review of long-bone fractures in patients with spinal cord injuries. Clinical Orthopaedics 155:65-70

RAGNARSSON K, SELL GH 1981 Lower extremity fractures after spinal cord injury: a retrospective study. Archives of Physical Medicine and Rehabilitation 62:418-423 